\title{
Dvě rusistické práce a jedna edice z ostrého zorného úhlu
}

\author{
Ivo Pospíšil (Brno)
}

Tatjana Avtuchovič: Ritorika. Žizň. Literatura. Issledovanija po istorii russkoj literatury XVIII veka. Minsk: „Limarius“, 2015. 412 s. ISBN 978-985-6968-45-0.

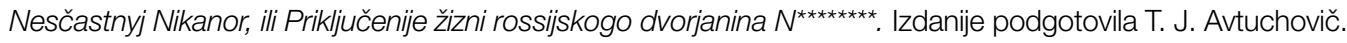
Literaturnyje pamjatniki. Sankt-Peterburg: RAN, „Nauka“, 2016. 334 s. ISBN 978-5-02-038353-1.

Tatjana Avtuchovič: „Šag v storonu ot sobstvennogo tela... “Ekfrasisy losifa Brodskogo. Slavica Sedlcensia, Opuscula, tom X, redakcja tomu Roman Mnich. Sedlce: Uniwersytet Przyrodniczo-Humanistyczny w Siedlcach, 2016. 267 s. ISBN 978-83-64884-21-4.

Grodněnská rusistka prof. Tatjana Jevgeňjevna Avtuchovičová (roč. 1951), která pracuje také na univerzitě v Siedlcích v Polsku, účastní se mezinárodních konferencích a sama je v Grodně organizovala a organizuje, mimo jiné pod názvem Vzaimodejstvije literatur $v$ mirovom literaturnom processe, se sama kdysi uvedla monografií o rétorice a románu, pojednáním o poezii rétoriky, učebním textem o antické rétorice a řadou edic a studií, v nichž se orientovala na to, co je jí nejbližší, tedy na rétoriku, poetiku a na prostor, v němž žije, tedy tzv. západní Rus, nynější Bělorusko, západní Ukrajinu a krajně západní část dnešní Ruské federace, kulturně tranzitivní teritorium, vyznačující se, dnešním jazykem řečeno, multilingválností a multikulturností, ale přirozenou, nikoli ideologicky vynucenou, samozřejmě v dotyku Pobaltí (Baltie) a polsko-litevské Rzeczi pospolité, v původním významu polsko-litevského soustátí, jakéhosi východoevropského United Kingdom. Sehrálo zásadní roli v evropeizaci Ruska a ruské kultury včetně umění a literatury, nebot tudy šly polské překlady z latiny a živých jazyků a překládaly se do jazyka u východních Slovanů všeobecně srozumitelného, tedy jakési směsi církevní slovanštiny a východoslovanských prvků, zejména v období baroka; na to se podíleli zde narození literáti, kteří potom skončili v Moskvě. ${ }^{1}$ Když se podí-

1 Viz např. naši recenzi na německou edici díla Lappa-Danilevského: Potřebná edice o ruském myšleni (Aleksandr váme na její publikační činnost konkrétně, je to již zřetelnější: podíl na vydání výboru z Fadděje Bulgarina, Vilno (Wilno, Vilna, dnešní litevské hlavní město Vilnius) jako křižovatka kultur ve dvacátých letech 19. století (vše ve spolupráci se známým grodněnským rodákem, roč. 1964, Alexandrem Fedutou/Aljaksandrem Fjadutou, text o rétorice, literárněvědné metodologii a poetice. Klíčovou je již její první velká kniha o románu a rétorice, jež pro ruskou literární vědu objevila - sice už jinde známý význam rétoriky jako stavebního kamene novodobé literatury a obnažila spor poetiky a rétoriky jako jasný i v literatuře 18.-20. století. ${ }^{2} \mathrm{Z}$ dalších témat se zabývala antropologií, kulturologií, ekfrází (viz dále), jestli se nemýlím, i dílem V. Rasputina, editovala řadu sborníků, jež se týkaly podstatných rysů literatury (četba a interpretace, autor a historická poetika, rétorika dialogu); sám jsem do některých takových publikačních výstupů

Lappo-Danilevskij: Politische Ideen in Rußland des 18. Jahrhunderts. Istorija političeskich idej v Rossii v XVIII veke v svjazi s obščim chodom razvitija kultury i politiki. Bausteine zur slavischen Philologie und Kulturgeschichte, Neue Folge, Bd. 1. Предисловие М. Ю Сорокиной. Подготовка текста М. Ю. Сорокиной при участии К. Ю. Лаппо-Данилевского. Böhlau Verlag, Köln - Weimar - Wien 2005). Slavica litteraria, X 9, 2006, s. 326327.

2 AVTUCHOVIČ, Tat'jana Jevgen'jevna: Ritorika $i$ russkij roman XVIII v. Vzaimodejstvija i načal'nyj period formirovanija žanra. Grodno: Grodnenskij gosudarstvennyj universitet im. Janki Kupaly, 1995. 185 s. 
přispěl a o Grodně a T. J. Avtuchovičové nejednou psal. ${ }^{3}$

Klíčovou je z této trojice první kniha, která je vlastně fundamentální ve výzkumu ruské literatury 18. století, o níž toho autorka mnoho napsala. Již v uvedené knize o rétorice a ruském románu 18. století, de facto její doktorské disertaci (DrSc.), se podívala na tento celek z nezvykle ostrého zorného úhlu v duchu boomu, jenž se na Západě prosadil už dříve: jak uvedeno znovuobjevení rétoriky a jejího podílu na výstavbě novověké a moderní literatury. ${ }^{4}$ Ale na poli výzkumu ruské literatury, zejména klíčového 18. století, které se někdy nazývá „dílnou ruské lite-

3 POSPÍŠIL, Ivo: Rétorika a ruský román (Tat'jana Jevgen'jevna Avtuchovič: Ritorika i russkij roman XVIII v. Vzaimodejstvija i načal'nyj period formirovanija žanra. Grodno: Grodnenskij gosudarstvennyj universitet im. Janki Kupaly, 1995. 185 s.). Svět literatury. Časopis pro novověké zahraniční literatury, 1997, č. 13, s. 116-119; týž: K sovremennosti i tradicijam brnenskoj slavistiki/rusistiki. In: Poetika i ritorika dialoga. Sbornik naučnych statej (k 60-letiju professora M. Je. Avtuchovič). Redkollegija: I. S. Skoropanova, T. F. Sem ‘jan, I. I. Plechanova, A. A. Korablev. Grodno: Grodnenskij Gosudarstvennyj Universitet im. Janki Kupaly, 2011, s. 25-38; Srednjaja Jeuropa kak perekrestok literaturovedčeskoj metodologii. In: Vzaimodejstvije literatur v mirovom literaturnom processe (Problemy teoretičeskoj i istoričeskoj poetiki). Materialy meždunarodnoj naučnoj konferencii, čast' 1. Grodno: Grodnenskij gosudarstvennyj universitet imeni Janki Kupaly, 1997, s. 3-10; The Reader-Listener in the Structure of a Genre as Part of the Reader's Functions in Literary Communication. In: Vzaimodejstvije literatur $\mathrm{v}$ mirovom literaturnom processe. Problemy teoretičeskoj i istoričeskoj poetiki. Materialy meždunarodnoj naučnoj konferencii. Grodno: Grodnenskij gosudarstevennyj universitet imeni Janki Kupaly, 1998, čast'2., s. 299-304; Grodno kak novyj vostočnoslavjanskij centr teoretičeskoj $i$ istoričeskoj poetiki. Russkij jazyk v centre Jeuropy 3. Banska Bistrica: Associacija rusistov Slovakii, 2000, s. 51-53; Roždenije srednejeuropejskoj poetiki (F. Kautman - O. Filip-J. Zogata - M. Viewegh). In: Vzaimodejstvije literatur v mirovom literaturnom processe. Problemy teoretičeskoj i istoričeskoj poetiki. Materialy X meždunarodnoj naučnoj konferencii v dvuch častjach. Meždunarodnaja associacija prepodavatelej russkogo jazyka i literatury, Učreždenije obrazovanija. Grodno: Grodnenskij Gosudarstvennyj Universitet imeni Janki Kupaly, 2005, čast' 1, s. 79-91.

4 Viz např. LACHMANN, Renate: Die Zerstörung der schönen Rede. Rhetorische Tradition und Konzepte des Poetischen (Theorie und Geschichte der Literatur und der schonen Künste, Band 93, neue Folge - Reihe A Hermeneutik Semiotik - Rhetorik, Band 8). München: Wilhelm Fink Verlag, 1994. Naše rec.: Wiener Slavistisches Jahrbuch, Band 41, Wien, 1995, s. 296-298. ratury“, tedy tranzitivním pásmem, poetologickou výspou ruské klasiky, to byl zásadně nový postup. V první studii o vzájemném vztahu rétoriky a literatury se $\mathrm{k}$ tomuto tématu, zejména na materiálu románu, zase vrací. Správně vidí, že rétorika je typ kultury, který byl sice načas potlačen poetikou, ale nikdy zcela nezmizel, tedy ani jeho vliv, vždy se objevuje znovu: rétorika tak funguje jako stavební kámen novodobé až moderní literatury a zvláště románu, který svou neobyčejnou strukturní flexibilitou sehrál úlohu kulturního mostu tím, že do sebe sebe vstřebal různé jiné žánry (viz „cizopasnickou“ roli románu u M. Bachtina), zůstal otevřený i k silovým prvkům rétorických žánrů a jejich žánrotvorných prostředků. ${ }^{5}$ Přitom, jak ostatně zní i název třetí kapitoly z oddílu o ruském románu a rétorice, byl tehdy román stále ještě výrazně marginálním útvarem v systému žánrů děděných z antiky přes středověk $\mathrm{k}$ renesanci, humanismu, manýrismu až po baroko, rokoko a klasicismus, i když už bylo vidět, že jeho postupy z něj činí žánr výrazně čtenářský, a tedy že často působí na poli masové/triviální literatury. Autorka ukazuje na to, jak „orátorské“, tedy rétorické prostředky vytvářely stylotvornou vrstvu v ruském románu 18. století, a posilovaly tak vliv rétorické kultury v literatuře té doby. Velmi podstatná je kapitola o překladové literatuře a jejím přerůstání v původní ruskou tvorbu a zde se sluší poznamenat, že překlady byly spíše „převody“ (pereloženija), resp. volné adaptace a že originální díla byla často založena na úpravě, modifikaci, transformaci původních děl a jejich ruských překladů. Tedy hranice mezi tzv. původními díly, jejich ruskými adaptacemi a originály, nověji zejména francouzskými a anglickými, je tenká.

Druhý oddíl se Romannaja ritorika vs. žizń je zásadním příspěvkem ke studiu vztahu rétoriky v románě a životním stylem doby, tedy přesněji druhé poloviny 18. století v Ruské ř́nši. Zde se autorka dotýká tématu, které ji v posledních

$5 \quad$ Viz také naši monografii Ruský román znovu navštívený. Historie, uzlové body vývoje, teorie a mezinárodni souvislosti. Od počátků $k$ výhledu do současnosti. Ed. Jaroslav Malina. Brno: Akademické nakladatelství CERM v Brně - Nakladatelství a vydavatelství NAUMA v Brně, 2005. 
letech plně zaujalo a které rozpracovala ostatně také v jiných textech. Jde mj. o diskurzní strategii ruského romanopisce 18. století, o kulturně sociální kontexty literatury, o ekfrázi, jednoduše řečeno, o popis výtvarného díla v literárním textu, o prózimetru v tzv. masovém/triviálním románu 18. století, o románu A. Nazarjeva Neštastný Nikanor, který posléze editovala, a o „neštastných“ hrdinech román 18. století. Vše souvisí se vším: je to jen vzorek prvků, z nichž se poetika ruského románu 18. století skládá, ale je dost průkazný a teoreticky nosný: to se znovu týká prózimetra, v němž je už materiálově viděn počátek románu jako takového. ${ }^{6}$ Poslední kapitola druhého oddílu už obsahuje složitější problematiku sepětí „neštastných“ hrdinů románů 18. století s dobovými ideovými proudy, zejména s osvícenstvím, ale také s klasicismem a preromantickým prouděním, včetně sentimentalismu. Co je v ruském prostředí nové, je vnímání rokoka, jehož vliv se konečně doceňuje. Ukazuje se, že ruská literatura 18. století skutečně vstřebala všechny možné poetologické, ale i rétorické impulsy v procesu, jenž jsme nazvali prae-post efekt. ${ }^{7}$

Třetí oddíl je už cele věnován sepětí idejí a životního stylu či způsobu života (Mir idej v zerkale byta). Avtuchovičová tu jde vlastně ve stopách ruských formalistů, kteří se od zkoumání poetiky, tvaru, formy, technologie dostávali - ales-

6 Viz ROHDE, E.: Der griechische Roman und seine Vorläufer. Leipzig, 1914; LUDVÍKOVSKÝ, J.: Řecký román dobrodružný. Praha, 1925; HÄGG, T.: The Novel in Antiquity. Oxford-Blackwell, 1983; KUCH, H.: Der antike Roman. Untersuchungen zur literarischer Kommunikation und Gattungsgeschichte. Berlín, 1989; WILLS, L. M.: The Jewish Novellas in Greek Fiction. In: The Greek Novel in Context. Ed. J. R. Morgan - R. Stoneman. London, 1994; BARTOŇKOVÁ, D.: Darés Fryžský a Diktys z Kréty a jejich misto $v$ antické literatuře. In: SPFFBU E 25, 1980, s. 223-234; táže: Letteratura prosimetrica e narrativa antica. In: La letteratura di consumo nel mondo greco-latino. Università degli Studi di Cassino, 1996, s. 251-264.

7 Viz o tom souhrnně: POSPÍŠIL, Ivo: Na forpostach teorii $i$ istorii klassičeskoj russkoj literatury. Colloquia Litteraria Sedlcensia XX. Siedlce: Instytut Neofilologii i Badań Interdyscyplinarnych Uniwersytetu Przyrodniczo-Humanistycznego w Siedlcach, 2015. 202 s.; Metodologija i teorija literaturovedčeskoj slavistiki $i$ Centraĺnaja Jeuropa. Colloquia litteraria Sedlcensia XXI. Siedlce: Instytut Neofilologii i Badań Interdyscyplinarnych Uniwersytetu Przyrodniczo Humanistycznego w Siedlcach, 2015. 172 s. poň někteří, hlavně B. Ejchenbaum - ke studiu literárního života (literaturnyj byt), tedy zhruba tam, kde jako mladý badatel začínal ve filozofickém pojednání o N. M. Karamzinovi. ${ }^{8}$ Charakteristické je, že se Avtuchovičová zabývá právě 18. stoletím. Nemyslím, že je to hlavně pro jeho tranzitivní povahu, spíše proto, že se tam tříbí především formální stavba literatury, která vzniká prolínáním poetiky a rétoriky, která tak v nové literatuře znovu nabývá na síle. Důležité také je, že zde Avtuchovičová analyzuje konkrétní souvislosti, jejichž význam právě v tomto století vzrůstá (J. R. Daškovová a její výchovný projekt). Podobně v další části se zabývá osvícenským projektem v reflexi současníků, potom jde opět o J. R. Daškovovou a tzv. životní prostor, o magii každennosti a nakonec o „divadlo mód“. Přesně Avtuchovičová postihla nástup čtenářství a význam čtenářské recepce a její rozhodující vliv na literaturu, vývoj triviální/masové literatury, z níž se vyvijí „vysoká“ literatura následujícího století a fakt, že se literatura stává běžnou součástí, každodenním faktem lidského života tím, že ho přesněji a detailněji reflektuje $\mathrm{v}$ jeho totalitě.

Kniha je neobyčejně faktograficky a interpretačně bohatá, obsahuje stovky odkazů k pramenné a odborné literatuře, současně je však zřejmé, že je zde poměrně málo cizojazyčné (mimo ruštinu) literatury a vlastně - nehledě na analýzu odborné literatury - méně vlastního srovnávání se západoevropskými literaturami, o nichž se sice hovoří, ale které se v srovnávacím modelu nevyužívají v původní podobě. To by mohl být i další výhled tohoto bádání. Je to v ruskojazyčném prostředí obvyklé: poukáže se na francouzské a německé nebo anglofonní koryfeje, které Rusové začali výrazněji respektovat až od devadesátých let minulého století a namnoze je také v rámci svých projektů překládají, ale svět světové rusistiky jako celku zůstává ve stínu. To je zejména překvapivé v případě anglického specialisty na 19. století Anthonyho

8 Viz naši úvodní studii Na křžovatce: René Wellek a některé genetické a typologické souvislosti literární vědy 20. a 30. let ve svazku POSPÍŚIL, Ivo - ZELENKA, Miloš: René René Wellek a meziválečné Československo. Ke kořenům strukturální estetiky. Brno: Masarykova univerzita, 1996. 
Crosse, emeritního profesora z Cambridge, jenž kdysi budoval také rusistiku v Leedsu a jiná slavistická pracoviště (setkal jsem se $\mathrm{s}$ ním v roce 1998 právě v Cambridgi), zakladatele 18th-Century Study Group a autora různých knih o britsko-ruských vztazích. ${ }^{9}$ Naopak potěší, když tam najdeme odkazy na rusky (nikoli česky) psanou knihu a studii Světly Mathauserové. Kniha T. Avtuchovičové patří $\mathrm{k}$ tomu nejlepšímu, co v ruskojazyčném prostoru v posledních 20-30 letech o ruské literatuře 18. století a pravděpodobně o ruské literatuře obecně vyšlo. I když její práce má i některé méně výhodné rysy východoslovanské rusistiky ve vztahu k Evropě, zejména střední, ukazuje ruskou literaturu z jiného zorného úhlu. Faktem je, že podobné úhly pohledu kultivovali i jiní, i když ne přesně totéž: měli však smůlu, že nepsali většinou rusky, anglicky nebo německy, dílem ani francouzsky.

Druhá kniha je vlastně pendantem první teoretické a historické: jde o průkopnickou edici románu 18. století, a to (zkráceně) Nesčastnyj (pův. Neščastnyj) Nikanor jakoby druhořadého romanopisce A. P. Nazarjeva. V Rusku vychází v současnosti stovky děl různých reedic, které vytahují ze zapomnění texty ruské minulosti. Jestliže za Gorbačova to byly většinou věci zakazované za sovětského režimu (,vozvraščennaja literatura“), nyní to jsou spíše zasuté texty staroruské, ale ještě spíše písemnictví 18. století, většinou ani nezmiňované v oficiálních dějinách ruské literatury nebo odkládané stranou jako marginální, tj. cestopisy, masová četba, sentimentální historie, různé nepůvodní texty, adaptace cizích děl apod. V takové edici vychází znovu i Nazarjevův román, jenž byl „upozaděn“ oproti např. románům otce a syna Fjodora a Nikolaje Eminových, M. D. Čulkova, A. N. Radiščeva nebo

9 Napr. CROSS, Anthony: In the lands of the Romanows : an annotated bibliography of first-hand English-language accounts of the Russian Empire (1613-1917). Cambridge, England, Open Book Publishers, 2014; týž: By the banks of the Neva: chapters from the lives and careers of the British in eighteenth century Russia. Cambridge University Press, 1997; People Passing Rude: British Responses to Russian Culture. Open Book Publishers 2012; Peter the Great through British Eyes: Perceptions and Representations of the Tsar since 1698. Cambridge University Press, 2000.
N. M. Karamzina. Sama četba tohoto díla, zvláště zahraničnímu čtenáři jinak jen těžce dostupného, je zážitkem zejména pro to, co uvádí sama pečlivá editorka, tj. reáliemi a psychologizací postav, jež dává nahlédnout do nitra tehdejších lidí více než jiná díla a než dokumenty doby. Editorka se řídila podle textologických zásad, které se spíše snaží dodržovat dobový úzus ortografický, ale i skladebný, morfologický, leč současně v kompromisním záběru se přiklání i k současným normám, pokud nějak nedeformují sémantiku a estetiku díla. To se myslím docela podařilo, i když bych ocenil ještě větší dodržování tehdejších zvyklostí, které by dnešnímu ruskojazyčnému čtenáři nevadily a cizímu čtenáři, jenž musí být znalcem vývoje jazyka i literárního kánonu a etikety, vlastně také ne. Ještě podstatnějš́ je studie Avtuchovičové o tomto románu, která v knize o 334 stranách zaujímá v podstatě 50 stran. Ze svých předchůdců tu navazuje zejména na V. V. Sipovského, což je zcela pochopitelné, nebot jde o největšího znalce a editora ruské literatury 18. století, zejména novely a románu, a V. Šklovského, který se dílem zabýval z tvarového hlediska; nemůže ovšem nezmínit ani v podstatě kritickou až negativní poznámku N. M. Karamzina, i když vzápětí ukazuje, kterak autor Ubohé Lizy vycházel vlastně z fraktury tohoto díla, považovaného v ruské tradici za druhořadé. Tradiční poukaz na Rousseaua a jeho La Nouvelle Héloïse, stejně jako na další dobová díla, je v traktování Avtuchovičové pojat poněkud jinak, nebot autorka vychází z autobiografických momentů díla a román označuje za biografický/autobiografický, když dosti podrobně zkoumá životní peripetie Alexandra Petroviče Nazarjeva. Upozorňuje na názor Jurije Lotmana, že román má „lubočný“ (lubok) ráz, odkazuje k dávné poznámce N. I. Novikova, ukazuje na experiment s rámcováním (jeho pozdější „rozptýlení) a v souvislosti s druhou a třetí částí románu (tu dopsal asi jeho příbuzný ze strany otce, kaprál a poté poručík Ivan Nazarjev, jenž pak přesídlil do Simbirské gubernie, měl syna, kterého pojmenoval příznakově Nikanor a ten se zase stal otcem provinčního spisovatele V. N. Nazarjeva (1830-1902). Snad nebude bez zajímavosti, když uvedu, že autor prvních českých, i když kompilativních, dějin ruské literatury a překladatel 
z ruštiny, ale i jiných slovanských jazyků Alois Augustin Vrzal (1864-1930) vedl korespondenci s někým z Nazarjevových, příbuzných A. Nazarjeva, snad s uvedeným V. N. Nazarjevem ${ }^{10}$ (Nazarjevovi jsou starý ruský šlechtický rod). ${ }^{11}$

Román je zvláštní jakoby protikladnou tendencí k heterogenitě, narativnímu experimentu, ale také naopak k jednoduchosti typické pro klasicismus, tedy k simplifikaci nebo, jak se nyní říká, k redukcionismu nebo, ještě lépe, k minimalismu. Nazarjev napíná svi̊j román do stran tím, že do něj vkládá poezii a další útvary; sám se stal autorem ód s lomonosovským pretextem, které editorka ve svazku uvádí. K edici snad už jen jediné: je to vynikající práce, včetně funkčních vysvětlujících poznámek, vše na vysoké editorské a textologické úrovni, studie je faktograficky nasycená, argumentačně přesvědčivá, jen srovnání se západní literaturou, jež by mělo být stěžejní, je jen letmé s využitím dosavadní tradice.

Třetí kniha vychází z dnes módního tématu ekfráze (ekfrasis), na nějž autorka naráží již v první knize. Zde se jejím objektem stal ruský básník, nositel Nobelovy ceny za literaturu Iosif Brodskij (1940-1996). Autorka vychází z tzv. nezbytí

10 Viz naši knižní studii a další články: Srdce literatury. Alois Augustin Vrzal. Brno: Albert, 1993; Alois Augustin Vrzal: A Catholic Vision of Slavonic Literatures. Slovak Review, 1992, No. 2, s. 166-171; Alois Augustin Vrzal a jeho duchovni dědictuí. Brno: Universitas, 1992, č. 6, s. 27-30; Alois Augustin Vrzal: Koncepce a dokumenty. SPFFBU, D 40, 1993, s. 53-62; Dva morarští slavisté: Alois Augustin Vrzal a Sergij Grigorovič Vilinskij. Slavia Occidentalis, t. 57, Poznań, 2000, s. 219-233; Alois Augustin Vrzal i Josef Jirasek i ich ocenka tvorčestva russkoj literaturnoj emigracii. In: Literatura russkoj emigracii. Ed. Zdeněk Pechal. Olomouc: Univerzita Palackého Olomouc, Filozofická fakulta, 2016, s. 154-165; Pervyj moravskij istorik russkoj literatury (A. Vrzal). Russkij jazyk v centre Jevropy, Banska Bystrica, 2001, č. 4, s. 56-61.

11 Viz https://ru.wikipedia.org/wiki/\%D0\%9D\%D0\%B 0\%D0\%B7\%D0\%B0\%D1\%80\%D1\%8C\%D0\%B5\%D0 $\% \mathrm{~B} 2 \% \mathrm{D} 1 \% 8 \mathrm{~B}$ ekfráze u Brodského hned v první kapitole a spojuje ekfrázi s rétorikou. V prvním oddíle Dialog s kulturoj. Metafizika ljubvi i tvorčestva se zabývá výtvarnými artefakty, které se v tvorbě Brodského objevují (Lucas Cranach: Venuše s jablky), a dále to rozvijí do tvrzení, že ekfrázový impuls může vést až k mytizaci a hovoří o podtextuu básně Zátiší (Natjurmort, naturmort). Další kapitoly obsahují analýzy ekfráze spojené ponejvíce s italským malířtvím (v souvislosti s G. B. Piranesim mluví o „obrácené“, tedy „invertované“ ekfrázi (s. 125). To, co je zde nejdůležitější, je pokus Avtuchovičové o svéráznou typologii ekfráze u Brodského (ekfráze jako metafora, mýtus, autoreflexe, autoportrét), která vede až k apologii umění v básni Ritratto di donna. V oddílu Poetika vizualnosti zajímavě zkoumá sovětský diskurs o Brodském a potom srovnává báseň Betlémská hvězda B. Pasternaka a I. Brodského, kde nachází stylizovanou ekfrázi jako interpretaci evangelijního syžetu. Jakýmsi závěrem je partie o poetice vizuálnosti u Brodského. To je podstatné: Brodskij je básníkem vizuálním a efráze je nástrojem či realizací vizualizace. Dříve se o ekfrázi sice mluvilo, ale nikoli tak důrazně: prostě se napsalo, že tématem básně je výtvarné dílo, nebo že je tam poezie spjata s maliřstvím, sochařstvím, psalo se o mýtu sochy, třeba u Puškina (R. Jakobson) apod. Je tedy kult ekfráze a její detailní vnímání tendencí, která je jistě zdravá ve smyslu detailního zkoumání vztahů různých druhů umění, ale současně trochu hyperbolizovaná v tom smyslu, že tímto důrazem, zaostřením jakoby lupou na jeden motiv ztrácíme celek obrazu i kdyžje ekfráze někdy úchytným bodem, na němž celá stavba díla, např. básně, spočívá, jindy je to však jen jeden z motivů. To třeba vždy esteticky zhodnotit. I třetí kniha T. J. Avtuchovičové má nutnou akribii a všechny náležitosti objevného spisu. Jistě je to příspěvek k hlubšímu poznání díla I. Brodského ale i k poznání anatomie a fyziologie ekfráze v literatuře i obecně.

prof. PhDr. Ivo Pospíšil, DrSc.

Ústav slavistiky, Filozofická fakulta, Masarykova univerzita

Brno, Česká republika

ivo.pospisil@phil.muni.cz 